\title{
Personalised service? Changing the role of the government librarian
}

Katherine Taylor

Knowledge Service, Rotherham PCT, Rotherham, UK

Sheila Corrall

Department of Information Studies, University of Sheffield, Sheffield, UK

Correspondence to: Sheila Corrall, Department of Information Studies, University of Sheffield, Regent Court, 211 Portobello Street, Sheffield, S1 4DP, UK. E-mail: s.m.corrall@sheffield.ac.uk

\section{Abstract}

Investigates the feasibility of personalised information service in a government department. A qualitative methodology explored stakeholder opinions on the remit, marketing, resourcing and measurement of the service. A questionnaire and interviews gathered experiences of personalised provision across the government sector. Potential users were similarly surveyed to discuss how the service could meet their needs. Data were analysed using coding techniques to identify emerging theory. Lessons learned from government librarians centred on clarifying requirements, balancing workloads and selective marketing. The user survey showed low usage and awareness of existing specialist services, but high levels of need and interest in services repackaged as a tailored offering. Fieldwork confirmed findings from the literature on the scope for adding value through information management advice, information skills training and substantive research assistance and the need to understand business processes and develop effective partnerships. Concluding recommendations focus on service definition, strategic marketing, resource utilisation and performance measurement.

Keywords: government libraries; information work; personalised services; value-added services.

\section{JIS}

Received: 25th June 2006

Revised: 24th July 2006 


\section{Introduction}

Successful professions constantly challenge their parameters and working environments. CILIP's report on Future Proofing the Profession highlights the need for library and information professionals to gain new 'information territory' and act quickly to capitalise on present opportunities.[1] This call for action is well-timed with changes in information provision and empowerment of end-users putting increased pressure on library and information services to justify their existence. St Clair argues that the nature of information provision has shifted from just-in-case to just-in-time to just-for-you.[2] Librarians can use their professional expertise to provide timely value-added information to satisfy the needs of people who feel overloaded with information. But they must be proactive and they must also have a firm grasp of the business processes within their organisation.[3]

In the UK Government sector, there is mounting pressure on librarians to demonstrate the value of their professional skills and prove to top management that the information services they provide are a vital resource in improving organisational efficiency and effectiveness, not a luxury commodity.[4] Pressure has intensified with the Gershon review of public sector efficiency, aimed at cutting civil service jobs and redirecting resources to the front line.[5] This has prompted some government librarians to identify new and innovative methods of service delivery, offering more personalised services and working more strategically with colleagues to better understand and meet their information needs.

In 2005, the Department for Education and Skills (DfES) Library conceived a plan to develop and implement a personalised model of service delivery, provisionally termed a 'Business Librarian' service, to run alongside the library's existing enquiry service, but expand on it by proactively tailoring and delivering information resources and consultancy services to meet the needs of specific projects, groups and teams (e.g. providing tailored advice on information and knowledge management issues or website design, setting up communities of practice and offering information skills training sessions tailored to very specific needs). Business librarians would liaise with particular teams and divisions, attend project meetings and awaydays, build up close working relationships with colleagues and take a highly proactive role in assessing, tracking and fulfilling their information needs.

Professional literature offers review articles, opinion pieces and case studies on the changing roles of librarians in the academic and corporate sectors,[6-9] but there is little published evidence or models to guide development and change in the government sector. Although the DfES proposal had some similarities with the 'Subject' or 'Liaison Librarian' role in the academic sector and the 'Clinical Librarian' role in healthcare,[6,10-11] the Library's view was that models which involved staff being permanently attached to particular work areas would not suit the project-based nature of DfES work. In this context, the Library commissioned an independent study to explore the feasibility of its proposed personalised service model and investigate the issues arising in terms of the remit of the service, its marketing, resourcing and measurement. The study thus had a practical business aim, but also hoped to make a contribution to wider professional thinking and practice; it was conducted over four 


\section{Personalised service? Changing the role of the government librarian}

months in 2005. This paper is based on an unpublished Masters dissertation, which provides full details of the study, including the research instruments.[12]

\section{Research questions and objectives}

Four research questions were derived from the brief:

- What services should the Business Librarian provide? (The service remit)

- How should the Library market this new service to DfES staff? (Marketing the service)

- How should the new service be resourced? (Resourcing the service)

- How can the value of the Business Librarian service be measured? (Measuring the service)

Five objectives were set for the study:

1. Identify existing ideas for the service and any constraints on the model.

2. Explore how the role of the librarian has changed in other sectors, including the academic, clinical and corporate sectors.

3. Investigate views of government librarians on the DfES service proposal and identify ideas of best practice. from those who have attempted to implement a similar model.

4. Identify expectations that will be placed on the Business Librarian service by DfES staff.

5. Make recommendations on how best to develop and implement the role of Business Librarian.

\section{Service context}

The DfES Library operates from two sites in London and Sheffield. At the time of the study it employed 22 staff, including 20 qualified librarians. The Library serves c4,000 employees of the DfES and associated agencies, based in London, Sheffield, Darlington and Runcorn. It operates a staffed enquiry service and maintains an intranet website, providing links to online journals and useful websites, in addition to information about all library services (e.g. current awareness, document delivery, skills training, advice and consultancy on copyright, metadata and other areas).

The proposed Business Librarian service was not envisaged as offering any new services, but as a re-packaging and tailoring of existing services to meet specific customer needs. Librarians would be informally contracted to particular projects for their duration and would spend time learning about the business of the teams supported to fulfil their information needs. The change would be in offering tailored services on a more systematic basis, becoming more proactive and extending specialist support to more work areas. 


\section{Literature review}

\subsection{Academic sector}

The role of the subject/liaison librarian in academic libraries is changing and its future is not assured. In 1996 Heseltine predicted its demise with the convergence of libraries and IT as learning support services, and in 2005 the University of Bangor announced the redundancy of eight subject librarians, whose role had supposedly been eclipsed by Google and other means of finding information on the Internet.[13-14] Other evidence is more positive, with growth in the number of such posts in the USA and convincing arguments for development of the role offered by Pinfield and Biddiscombe in the UK, and Frank and Howell in the USA [6,15-17]. Many writers now see liaison activity, not subject expertise, as the defining characteristic of the role and the means of ensuring its future; communication and IT skills, combined with a flexible approach and a broad understanding of their academic customers' activities, are therefore more important than in-depth disciplinary knowledge.[6,15-16,18]

Frank and others argue that liaison programmes are too passive: librarians need to move beyond traditional service models to become more dynamic 'information consultants', providing proactive value-added customised services. Change is required because of developments in scholarly communication and information seeking behaviour, with desktop access to resources: librarians need to redefine their services before other information providers take their place.[10,19-20] Commentators emphasise the increased importance of information literacy and development of their training/teaching role, often linking this with involvement in e-learning and virtual learning environments: librarians need to work more closely with academic colleagues to integrate information literacy into curricula, develop their technological and pedagogical skills, and reposition themselves as learning support professionals and/or teachers.[16,21-22]

\subsection{Health sector}

Information professionals in the health sector are claiming new territory, particularly through evidence-based practice and information literacy initiatives. Evidence-based healthcare is providing new roles for librarians, who are getting involved in systematic reviews - locating evidence, filtering and appraising literature, adding value to information and furthering knowledge.[23-24] They are also providing information at the point of care, in clinical practice and in partnership with primary healthcare services.[11,25] The role of the clinical librarian, first discussed in the 1970s, has regained prominence in the 1990s, with renewed emphasis on evidence-based practice requiring high-quality up-to-date evidence to be considered in deciding medical treatment.[11] Clinical librarians use specialist skills and knowledge, gained on the job, to synthesise complex information and repackage it for clinicians.[26] 


\section{Personalised service? Changing the role of the government librarian}

To fulfil these roles successfully and work across professional boundaries, librarians must be fully aware of the benefits their services can bring.[27] They must work collaboratively and prove they are in 'real business' by being quick to adopt new technology and constantly updating their skills, which they must sell to colleagues and clients.[1] Palmer argues that changes in healthcare information provision reflect changes elsewhere: users now demand seamless access and self-service, with information customised to meet specific needs and librarians providing outreach services alongside traditional offerings. CILIP's research showed many staff were ill prepared or reluctant to take on these roles.[1,28] User education and information skills training to make users more selfsufficient have also grown in importance: a survey of clinical librarians showed $91 \%$ offered user education sessions and many NHS libraries provide instruction on a one-to-one basis.[26,29]

\subsection{Corporate sector}

Similar themes emerge from the corporate sector. Wittwer stresses the need for librarians to keep a close watch on developments in their parent organisations, spend time building good working relationships and become real partners with their customers and colleagues: they must keep up-to-date with new technology, self-promote and add value to the information gathering process (e.g. by providing advice on knowledge management and training on navigating resources.[3] Special librarians are moving beyond the traditional intermediary role to providing customised information, using their knowledge of the business to filter, verify, analyse and summarise material, in order to deliver it in a timely and cost-effective manner - which means not just fulfilling, but actively anticipating, user needs.[2,30]

The key to success lies in anticipating the needs and direction of the organisation before occurrence, which in turn depends on understanding the organisation's business operations. Konieczko and Powell argue that librarians needs to immerse themselves in business planning processes outside the library to develop tailored services that will drive organisational productivity.[8] Barreau points out that increased visibility leads to greater accountability - and stress - for library and information professionals, but the benefits include being more able to define their role in the organisation and better equipped to meet its information needs.[31] Ryan emphasises the need to be proactive in suggesting resources to customers and taking every opportunity to 'walk the territory' to meet users, in view of the constant need to justify existence.[32] This echoes Brick's call for business libraries to be much more proactive in identifying and targeting non-users, making this integral to their marketing strategies.[33]

\subsection{Government sector}

The literature on government library and information services is sparse in comparison. A central theme, notably in the journal of the Network of Government Library and Information Specialists (formerly the Circle of State 
Librarians), is the need to move towards more intensive user training, boosting civil servants' information literacy skills, so that they can conduct their own research efficiently.[34-37] Echoing academic librarians, Miller argues that government librarians are information experts, not subject specialists: they should be teaching colleagues to search for their own information and developing more independent end-users, which will result in a more efficient and effective organisation and the creation of new knowledge.[36]

The librarian's role in supporting knowledge management across government is another important theme. Documented examples include the Defence Science and Technology Laboratory (Dstl), the Financial Services Authority, HM Customs \& Excise, HM Treasury and the Home Office.[38-42] This role includes providing advice to teams, as well as involvement in organisation-wide knowledge management strategy and implementation. At Dstl, a team of information and subject experts, known as 'Knowledge Agents', provides ontap responses to colleagues' information-related needs. Team members have diverse backgrounds, including information work, but operate separately from the library, as a self-financing unit. They have a boundless service remit, from basic literature searches to complete support for the information needs of a major project, offering a wide range of consultancy skills to support the business, adding value to information and enabling knowledge creation and sharing.[35] At the Home Office, librarians are actively involved in knowledge sharing initiatives and argue that they are well placed to do so, because of their background in sharing information and teaching others how to handle it effectively.[42]

\subsection{Service marketing}

Information professionals are taking a more strategic approach to marketing their services, especially in the academic and corporate sectors.[30,33,43-45] The profession has also recognised the relatively new concept of 'relationship marketing' as particularly relevant to library and information services in the context of developing closer working relationships and partnerships with customers and colleagues: customer relationship management offers mutual gain, as the process of building the relationship enables the service provider to become more attuned to and thus better placed to satisfy customers' information needs. [44-49]

Branding is another key concept gaining attention in academic, national, public and (particularly) special libraries.[30,45,50-54] Libraries need to position themselves as the primary conduits of information in their organisations.[30,45] This includes the important task of naming the service. Ryan renamed his service 'Business Information Centre' to counteract negative preconceptions of the words 'library' and 'librarian'.[32] Biddiscombe similarly believes the term 'librarian' is unhelpful, suggesting 'learning development adviser' as a more accurate label for the academic subject/liaison role.[16] However, Shamel argues that the name matters little, as long as the brand is consistent and marketed strategically.[30] 


\section{Personalised service? Changing the role of the government librarian}

\subsection{Performance measurement}

Information professionals are also adopting strategic approaches to measuring the impact of their services, with increased pressure to demonstrate value for money. New roles require new types of measures: Scherrer and Jacobson identify consultation, outreach and web authoring as requiring new quantitative or qualitative measures.[7] The pressure to demonstrate value is particularly acute in the corporate sector, where it is a longstanding concern.[55] Ryan believes 'time saved' is the only quantifiable measure in information provision.[32]

Matthews reviews evaluation methods and recommends a 'Balanced Library Scorecard', an adaptation of the Balanced Business Scorecard, now widely used in both private and public sectors. This tool connects measurement with strategy and vision, encouraging a broader view of performance than traditional metrics.[55] It is gaining support within the profession, with a growing number of case studies of academic, national and special libraries.[56-62] Of particular interest here is the example of a 'Knowledge Management Benefits Scorecard' (including quantitative and qualitative measures) at the Financial Services Authority.[39]

\section{Research methods}

\subsection{Study design}

A qualitative methodology was chosen as most suitable for a real-world project with a small-scale in-depth focus; Its exploratory nature required a methodology sensitive to the context and sufficiently flexible to allow issues and questions to be investigated as they emerged. The approach was inductive, rather than hypothesis-led, with no prior assumptions made, thus allowing theories to emerge as themes and patterns from the data as they were interpreted; the grounded theory approach is particularly suited to exploring topics ignored in the literature.

The methods used comprised a review of the literature, to explore changing roles in other sectors, including developments in marketing and measurement; a survey of government librarians, to gather experiences and opinions of personalised service models; and a survey of DfES employees to gather experiences and opinions of existing and proposed services.

Questionnaires were used to gain a broad overview, followed by interviews to obtain in-depth understanding. Combining these methods allowed the collection of some quantitative data on service usage to balance and contextualise the detailed opinions mainly sought. The multi-method approach enabled different sources of information to be tested against each other, thus achieving triangulation and improving validity. Both face-to-face and telephone interviews were used to include a larger number of geographically dispersed participants than would otherwise have been possible. 


\subsection{Sampling strategy}

Purposive sampling was used to target participants thought likely to make a useful contribution. The government library questionnaire was distributed to the Committee of Departmental Librarians (CDL, representing 24 service heads). The government interview sample originally comprised five librarians with known experience of running personalised services, but was later expanded to compensate for a low questionnaire response rate (four). This enabled participation of more staff directly involved in service delivery and coverage of 11 government libraries. Within the DfES, contacts in the Library and the DfES Learning Academy were used to target likely users of the Business Librarian service, existing users of library services and some non-users. The questionnaire was sent to 45 people, obtaining 27 responses, with 11 agreeing to be interviewed.

\subsection{Data collection}

Both questionnaires used a mix of open and closed questions, to gain the desired balance of qualitative and quantitative data and encourage responses with questions that were easy and quick to answer. Space to expand on answers to closed questions was provided. The instruments were rigorously piloted. They were distributed electronically.

The CDL questionnaire had two sections: one was directed at libraries offering personalised services, seeking information on their remit, marketing, resourcing and measurement, problems in gaining acceptance and lessons learned; the other asked respondents not currently offering personalised services to consider their advantages and disadvantages. Telephone interviews with government librarians used the same questions, but aimed for more detailed responses from participants selected for their operational experience of personalised services.

The DfES questionnaire also had two sections: a shorter first section explored usage levels for existing services; the second explored levels of interest in the proposed service, perceived benefits and management arrangements. Interviews with DfES staff were semi-structured, using a mix of closed and open questions: some covered the same areas as the questionnaire, others were new and a few related specifically to individuals' questionnaire responses. A key objective was to gain increased understanding of respondents' information needs and ways the new service could meet them. An interview script was used, which first reminded participants of the Business Librarian concept and then described two scenarios showing how the model might work in practice.

\subsection{Data analysis}

Detailed notes were made of telephone interviews and written up immediately; face-to-face interviews were recorded, with additional notes also taken and written up later. Qualitative data were analysed using the constant 


\section{Personalised service? Changing the role of the government librarian}

comparative method: codes and categories were assigned, constantly compared and adapted as new codes emerged, aiming to generate concepts and theory that were central to (grounded in) the data.[63]

Raw data (questionnaire responses and interview notes) were first split into distinct parts using open coding. Connections and relationships were then identified and assigned axial codes, which were finally grouped into core categories with selective coding, to give a higher-level picture of the research data and emergent thinking. Tables were used to define the codes and relationships at successive levels. The small sample sizes enabled relationships in the quantitative data (responses to closed questions) to be identified without statistical tests.

\section{Results}

\subsection{Government librarians}

\subsubsection{Adoption and rationale}

Four out of 11 libraries offered a personalised service, two had offered one previously and two others would consider implementing one in the future. Reasons for not adopting this model were insufficient staff resources and dispersed user bases: departments with offices and staff spread across many sites felt it would be harder to identify potential users and to deliver the service. Reasons for considering implementation centred on the opportunity to extend the reach, increase the impact and raise the profile of the library, in ways that the traditional service could not do on its own.

\subsubsection{The service remit}

The remits of existing and previous personalised services were extensive and varied, including tailored workshops, database and thesaurus construction, current awareness, literature searches and in-depth research. Two current and the two former services were based on 'cherry-picking' groups to work with, rather than opening up the service to the whole organisation. One library concentrated on working in partnership with a few chosen contacts, rather than carrying out ad hoc research requests; it provided research to support evidence-based practice, which meant building up an in-depth understanding of colleagues' business needs.

\subsubsection{Marketing the service}

Marketing strategies reflected the inclusive or exclusive nature of the services. Two marketed their services extensively, using a variety of techniques, including presentations to business units and project managers, publicising services at induction events and through in-house publications, and emailing success stories to colleagues; both found word-of-mouth to be a significant way of generating demand. In contrast, the cherry- 
pickers deliberately under-marketed their services, to limit demand and manage user expectations: they picked up work through networking, selective targeting and repeat business.

\subsubsection{Resourcing the service}

Resourcing strategies indicated different management philosophies: three used dedicated staff to provide the service, with one drawing a clear distinction between "researchers" and "librarians"; but the others deliberately involved all their librarians, to exploit and develop expertise, and avoid an "us-and-them" situation making excluded staff feel deskilled. Only one had a structure whereby individual staff built up expertise and contacts in specific subjects/divisions. Two stressed the need to prioritise and balance workloads in order to run the service alongside other commitments. Three imposed some charges, typically for team-specific resources or projectrelated costs; one occasionally charged back the costs of casual staff employed to cover a librarian engaged on a special project.

\subsubsection{Measuring the service}

Four libraries used performance indicators to gauge service impact and success. Measurements included the amount of time spent on projects, numbers of enquiries received, accolades and repeat use. Two used feedback forms at the end of projects and one tried to find evidence of librarians' contributions to projects influencing outcomes. One library was developing a database to record outcomes of enquiries undertaken and another was considering using a balanced scorecard in future.

\subsubsection{Gaining acceptance}

Four libraries had experienced problems in gaining recognition of their skills and services from colleagues. Strategies to overcome this included asking the divisional head to sell the benefits to teams and getting involved in the business planning process, to increase visibility and build mutual understanding. Two reported initial concerns of librarians about workloads had been resolved by a flexible approach to task allocation, with other staff absorbing work as needed.

\subsubsection{Lessons learned}

The main points related to clarifying requirements, managing workloads and targeted marketing.

- Full involvement at the project initiation stage is crucial to ensure a clear, shared understanding of objectives and timescales. This should be followed through with frequent communication during the project, to guard against inadvertent changes in deliverables.

- The ability to prioritise work quickly and effectively is vital. It is also essential to have mechanisms for dealing with staff absences, such as fact sheets and guidelines, to provide continuity of service. 


\section{Personalised service? Changing the role of the government librarian}

- Marketing should target knowledgeable existing customers first, to gain some quick wins and create an indispensable service. Early successes can provide a platform for educating other potential users on what the library can do and for defending the service, if necessary.

\subsection{DfES employees}

\subsubsection{Existing service usage}

Eleven out of 27 respondents used existing library services at least once per month, of whom five used services at least weekly. Eight used it less often and others did not use it (or did not comment). Figure 1 summarises current levels of usage for particular services, showing relatively high usage of current awareness, general questions, journal consultation and book loans, with lower levels for consultancy services, in-depth questions and training sessions.

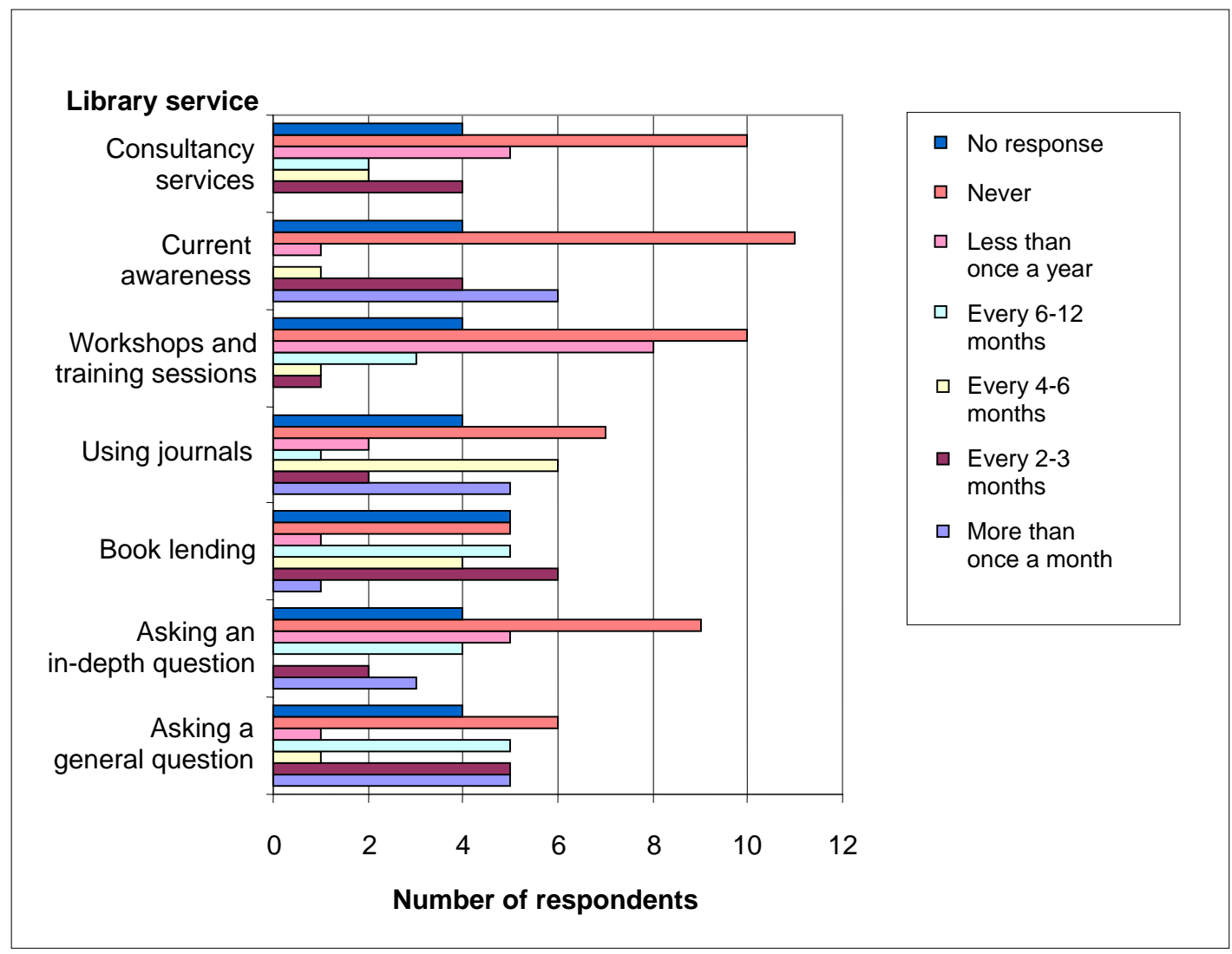

Figure 1 Levels of usage for existing library services 


\subsubsection{Proposed service interest}

Thirteen out of 27 respondents said the proposed Business Librarian service would definitely be useful to their teams and two said it might be useful. Seven said it would not and the rest did not reply to this question. Figure 2 shows the levels of relevance assigned by respondents to specific services, indicating much higher levels of interest in (tailored) training sessions and (particular) consultancy services, than suggested by the data for current levels of usage, e.g. Figure 1 shows that 10 staff said they never used library consultancy services, but Figure 2 shows relatively high numbers saying they would find advice on website design, metadata, controlled vocabularies and intranet communities very or fairly useful.

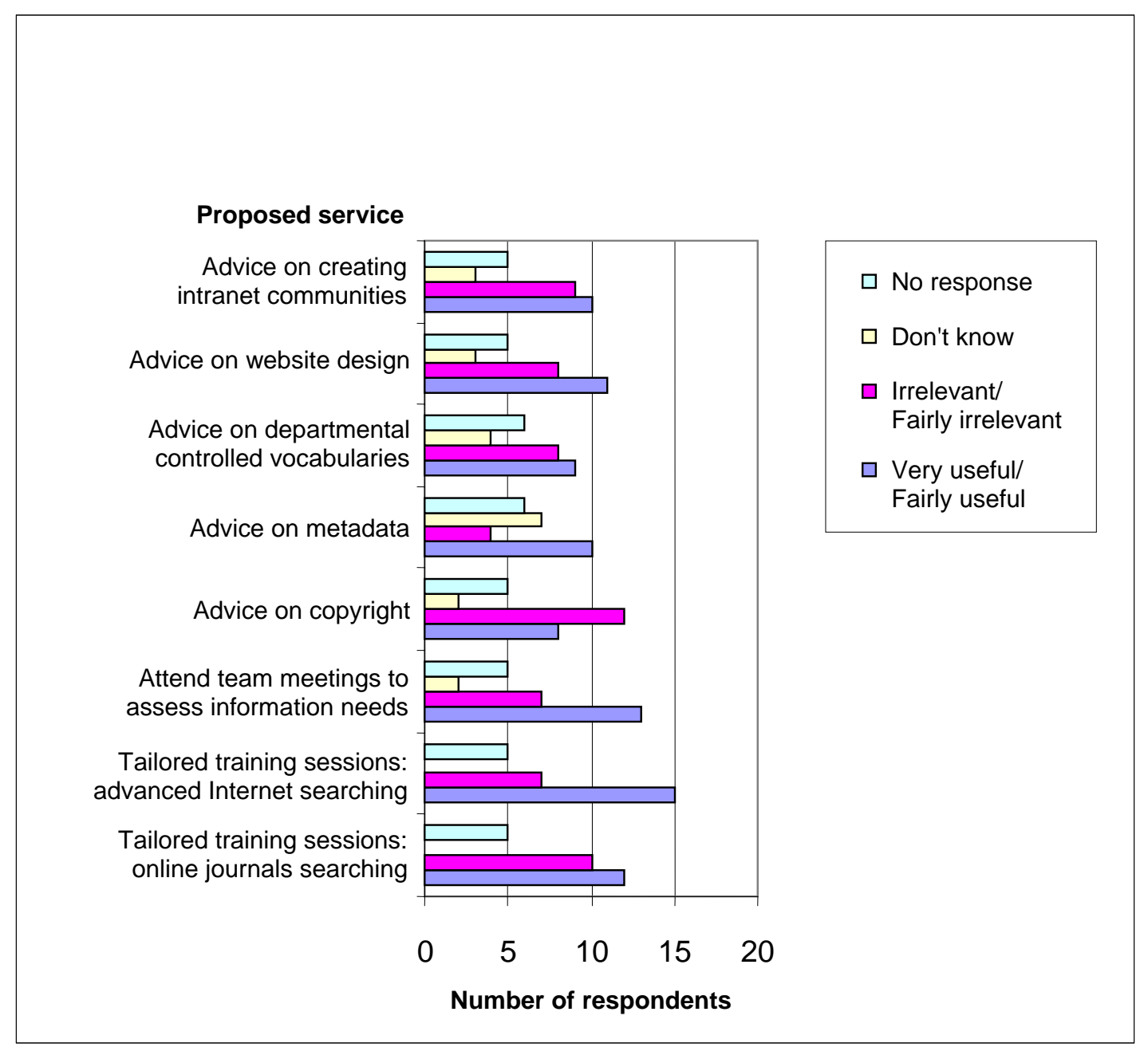

Figure 2 Levels of interest in proposed tailored services 


\section{Personalised service? Changing the role of the government librarian}

These results suggest there may be more scope for the Library to deliver consultancy and training through a tailored Business Librarian service than via its traditional service model. This preliminary endorsement of the service concept is reinforced by 13 positive responses to the proposal for librarians to attend team meetings to assess their information needs.

\subsubsection{Exploiting professional skills}

Analysis of the qualitative responses to the DfES questionnaire and interviews identified three overarching themes. The first (labelled 'professional skills') highlighted potential benefits of the Business Librarian model in making better use of librarians' specialist professional expertise. Comments showed many respondents felt that the professional skills of librarians could significantly help DfES employees and add value to their work. Three key areas were identified: information management advice, information literacy training and research assistance.

On information management, four interview respondents mentioned a need for help with website design (e.g. to create metadata and improve search facilities) and none had thought of asking the library for assistance. Three staff identified different ways in which a librarian could advise teams on knowledge management: by helping to structure and organise their information, helping to organise and improve their intranet community, or helping members cope with high volumes of email.

On information literacy, three questionnaire respondents had concerns about information overload, with Respondent 1 highlighting a consequent failure to access a full range of sources, "There is a need to make better use of all the sources of information. At present [the team] does not draw on all of them." Five interview respondents identified specific training needs, such as learning how to keep up-to-date with key authors or journals and leading thinking in the field; how to search for information more efficiently; and how to judge its quality and reliability.

On research assistance, several respondents were keen for librarians to carry out research on their behalf, particularly to scope the wider environment and help teams access a broader range of sources. Staff talked about the risk of civil servants being "myopic", mentioning difficulties in keeping up with current information from a broad range of sources and a consequent tendency to look at research findings in isolation. Librarians could conduct horizon scanning to help broaden their research and find the most current and relevant information. Other suggestions included assistance with researching Parliamentary Questions (PQs), evidence-based policy development and literature reviews, where library expertise get the work done more quickly; and this would raise the library's profile, as such work is often at the cutting-edge policy level. 


\subsubsection{Marketing the service}

The second overarching theme was the importance of marketing the service effectively and strategically. Respondents identified three related issues: targeting the service, raising its profile and defining it effectively.

On targeting, staff expressed different opinions on the organisational level at which the service should be pitched, ranging from the individual to the directorate (the top-level organisational unit). Respondent 7 said the way the library markets the service would determine its success, then observed “...but I don't have a team, I am a personal performer; it may relate more to subject specialists than teams." Suggested approaches included: targeting teams at the hub of project activity, to raise the service profile; getting involved in meetings at divisional level, to make more impact, as teams are often small; and having librarians dedicated to each directorate (adopting the 'account manager' model used successfully by other teams in the Corporate Services and Development Directorate), to become involved in higher-level discussions.

On profile-raising, several respondents felt the proposed model would increase awareness of the library and its services, by improving rapport with colleagues, establishing points of contact, keeping the library in people's minds and encouraging more effective usage. Respondent 3 noted “...it is not high up in people's consciousness, even though the library always helps when they are approached and provides a good service". Two respondents wanted named business contacts, in line with other central services, “...not to do every bit of research, but someone to turn to with more expertise to dig things out quickly" (Respondent 3). One respondent mentioned using contacts in Analytical Services to track down reports, which could probably have been located more efficiently via the library.

On defining the service, one explanation for non-use was found in low awareness of services, typified by Respondent 9, “I don't know what services you can provide that would be helpful to me”. Respondents were also confused by perceived overlaps between library services and those of other units, such as the Learning Academy and Press Office. One acknowledged the potential in the Business Librarian service, but emphasised the need for librarians to make contacts, raise their profile and know the business: people needed to understand exactly how these services could help them in their work and librarians needed to understand exactly what they required. Closer seamless working was needed among the central services and the proposed information needs assessments could support this process.

\subsubsection{Logistics}

The third theme running through responses covered the practical aspects (or 'logistics') of delivering the service. The main issues discussed were timescales and timing for involvement, channels of communication and the use of service level agreements (SLAs).

The variety of work made it difficult to generalise about timing of engagements. Many people wanted librarians to have inputs to projects for short periods and specific purposes, but to build relationships encouraging repeated 


\section{Personalised service? Changing the role of the government librarian}

involvement. The majority view favoured involvement at or near start-up, when people are thinking about the kind of information needed; one said this planning phase would last two or three weeks at least; another said it could be useful for librarians to come in again later in projects. For other undertakings, involvement after foundations had been laid might be a better use of time. Three respondents estimated a librarian might be involved with meetings, phone calls and emails for one day in total, but spread across a three-month project. Other work could be time-consuming with tight deadlines, such as gathering information for a Bill, having just a few hours to research a PQ, or five days for a literature review.

Four respondents identified email as their preferred form of communication, but advised combining it with faceto-face discussion through individual contact and/or team meetings, and backing up discussions with written communication. Project start-up meetings were mentioned as a way in for librarians, but it was also suggested they should take the initiative and invite teams to meetings to discuss skills and services on offer; information needs assessments were also seen as a useful way to kick-start relationships. One respondent suggested designating one of his team as the named contact (liaison) for the Business Librarian service, building on his previous suggestion that the library should designate named contacts for teams/divisions. Communities of practice were the least popular mode of communication: not all staff belonged to one and those who did felt their communities were under-utilised and not yet fully embedded into working practice.

Opinion was split on whether an SLA would help to define and tailor services to needs: nine questionnaire respondents answered positively, 11 negatively, and one said 'Possibly'. Interview responses were similarly mixed: some felt SLAs were restrictive, bureaucratic and unnecessary for a proactive service; others were in favour and saw them as potentially useful. In contrast, respondents generally welcomed the proposed information needs assessments, which could serve as a first step towards a more formal customer-provider understanding.

\section{Discussion}

\subsection{Feasibility of the model}

The literature showed a shift towards providing tailored, personalised information to combat information overload. In the academic and health sectors, subject and clinical librarians still have an important liaison/consultancy role in meeting the information needs of particular groups.[15-16] Clinical librarians are supporting evidence-based practice by adding value to information through the systematic review process.[23-24] Corporate librarians are using their specialist information skills in consultancy and partnership roles.[2-3] Government information services are increasingly moving towards tailored services, with a particular focus on information literacy [34-36] and knowledge sharing [38-42]. 
Government participants in this study confirmed their interest in providing personalised services, through increased liaison and consultancy roles, contributing their professional expertise to specific projects and building up closer working relationships within their organisations; one said it was "imperative" to move beyond purely enquiry-desk based services to fulfil the information needs of their organisations and ensure their own survival. Wider research also suggests it is not only feasible for librarians to offer a more personalised service, but essential if their skills are to be recognised and valued.[32] There are significant opportunities to manage and add value to information and empower the end-user with information literacy skills; but librarians need to be more proactive, to understand the complexities of users' specific information needs and raise their status within their organisations.

The DfES survey confirmed this picture, showing a majority of respondents were keen to use the Business Librarian service and interested to know how it could help their day-to-day work. Most respondents used the Library sporadically and it was not strongly embedded in their consciousness as a primary information resource. Some used inappropriate or inadequate sources, which could limit the scope and effectiveness of their research; many also suffered from information overload. Despite low usage of existing services, staff responded positively to receiving these services through a more tailored Business Librarian service and were keen to receive tailored training and advice on website design and metadata. They also saw librarians' skills as useful in supporting evidence-based policy making, by providing information literacy training and current awareness services.

Library services were highly valued when used, but needed to be re-packaged and delivered differently to increase usage levels. There was low awareness of the types of service available and limited understanding of many specialist services. The Business Librarian service has the potential to raise awareness of librarians' skills at an individual, team, divisional/directorate level. The model also reflects wider government thinking on streamlining and efficiency: it would make better use of librarians' professional expertise and help DfES staff to manage knowledge, become information literate and fully utilise all the research sources available to them.

\subsection{Defining the service remit}

DfES services reflect those offered by other government libraries and in other specialist library sectors. Konieczka advises special libraries moving to a more proactive role not to try to be all things to all people, underlining the need for a well-defined strategy and targets.[8] The DfES Library must consider whether it has the capacity to take up respondents' suggestions that librarians should carry out substantive research work: should it follow the government library which draws a clear distinction between "researchers" and "librarians", or follow Miller's advice and concentrate on information literacy training to make (non-library) researchers more able and independent?[36]

There is a clear need to define the service offer, as many users are unsure what it is. This need for clarity also applies to specific project engagements, as one lesson learned from government librarians was the importance of 


\section{Personalised service? Changing the role of the government librarian}

defining and confirming requirements, objectives and deliverables at the start and during projects. While there was a mixed response to SLAs for the Business Librarian service, respondents were consistent in wanting further guidance on the service scope, including its relationship to other central services. They also supported the proposed information needs assessments - which could fulfil some of the usual SLA functions - and specifically advocated documenting the outcomes of discussions with individuals/teams about their requirements.

\subsection{Marketing the personalised service}

Library marketing is about predicting and satisfying customers' needs profitably - in a mutually beneficial way rather than trying to sell them things they do not need.[45] According to Soules, libraries perform such a diverse role that it is often difficult for people to know what they offer.[44] This proved the case at the DfES, where usage of training and consultancy services was low (Fig.1), but demand for these services was identified when presented as specialist tailored support (Fig.2). The Business Librarian model has the potential to market and deliver these services more effectively and defining the service needs to be part of the marketing strategy, which must also extend to non-users.[33]

The research reinforced the professional literature's emphasis on marketing the service strategically. Government librarians favoured targeting services at particular projects and business units; one had sought assistance from a divisional head in selling the service to teams. DfES staff confirmed project teams as the core constituency for the service, but also suggested engaging more strategically at the divisional/directorate level, providing named contacts or 'account managers' and working more closely with other staff in the Corporate Services and Development Directorate.

DfES respondents advocated a mix of email and face-to-face communication, especially project/team meetings, to build the service and manage customer relationships. The Library had suggested marketing the service through existing intranet communities, but responses revealed such communities were not sufficiently embedded in practice for this to work, though they could be used to identify project teams and groups with shared interests.

The Library evidently needs to build a stronger brand, as it is not currently seen as the primary conduit for information in the department.[30,45] However, the antipathy to the terms 'library' and 'librarian' met elsewhere does not seem to be an issue here, as the name 'Business Librarian' was only queried once in discussion.[16,32]

\subsection{Resourcing a successful service}

If the proposed service is as successful as the results suggests it could be, this would mean increased library workloads, with a requirement to engage with projects at short notice and deliver work to tight deadlines. The Library has indicated it does not have the resource to operate like dedicated subject/liaison librarians in a university, nor to embed librarians into particular teams for extended periods. Lack of staff resource was one of 
the main reasons given by government librarians not offering personalised service and those operating one highlighted workload management as a key issue. The survey revealed two distinct operational models: the dedicated research team, where librarians specialise in this service; and the unified whole-service approach, where all librarians participate in its delivery. The second model offers more flexibility, pooling staff expertise, developing more people and guarding against silos. It requires close monitoring and prioritisation of workloads, but seems better suited to the circumstances and ethos of the DfES Library.

Government librarians make limited use of charges to finance their services. The only relevant self-financing service identified (Dstl) operated outwith the library.[38] There are thus few precedents for charging; the internal situation at DfES does not seem opportune for introducing charged services and any charges made by the Library would need to be clarified in marketing the service, as one respondent identified this as a likely deterrent.

\subsection{Measuring the value added}

The importance of libraries adding proven value to their organisations is a burning issue across all sectors. It has particular significance for government libraries in a climate of efficiency gains and public expenditure cuts. Personalised services can exploit professional skills to increase organisational efficiency, but their worth needs to be measured in ways that are recognised by senior managers. Most librarians accept the importance of measurement, but identification of suitable measures has lagged behind service development, with key areas such as outreach and consultancy still lacking adequate performance indicators.[7] Some libraries are now moving their measurement activity on to a more strategic level with Balanced Scorecards.[56-62]

The DfES Library plans to measure its new service by recording activity in its customer enquiries database and collecting feedback through end-of-project interviews, using quantitative and qualitative data. Both approaches reflect existing practice among government librarians, who also mentioned time spent, repeat use and accolades as indicators; only one was considering a balanced scorecard. In the corporate sector, time saved for the firm has often been cited as the key measure; but increasing numbers of organisations, including both corporations and government agencies, now favour the broader view offered by the balanced scorecard, which is an argument for libraries to consider this system.[32,55]

\subsection{Limitations of the study}

Only two out of 27 respondents to the DfES survey were not existing library users and all those who agreed to be interviewed were frequent users. The results were thus not fully representative of the potential user base for the proposed service. Although the response rate to the CDL survey was poor, expansion of the government library interview sample achieved an acceptable level of participation (11 out of 24 departments). Nevertheless, nonresponder bias needs to be borne in mind when considering the findings from both areas. 


\section{Personalised service? Changing the role of the government librarian}

The particular focus of the study limits its value in terms of generalisability. Its main aim was to provide contextspecific recommendations to the DfES Library, but it has drawn on thinking and practice across the UK government library sector and may in turn influence future thinking and practice in that sector. The findings have been related to the wider library and information services environment and the key messages may be relevant and transferable to practice in other sectors.

\section{Conclusions and recommendations}

This study explored the feasibility of a personalised model of service delivery (the 'Business Librarian' model) for the DfES in the context of changes in information provision, empowerment of end users and pressures on information professionals to demonstrate the value of their specialist skills to their organisations. It adopted a qualitative methodology, using an inductive grounded theory approach, to explore the opinions of DfES staff and government librarians on the remit, marketing, resourcing and measurement of the proposed service. Primary research data were analysed systematically using coding techniques to identify key themes, which were discussed in relation to developments in academic, health, corporate and government information services. Although conducted within a specific context, the findings should be of interest to other information service managers.

The main finding from the study was that the proposed Business Librarian service is not only a feasible model, but a necessary development, to ensure effective and efficient use of information and expertise within DfES. The research showed low levels of usage and awareness of the specialist library services currently provided, such as information skills training and information management consultancy, but high levels of need and interest in these services when presented as elements of a package offered by a Business Librarian. The Business Librarian service could help to solve these problems, by advising staff on information management, training them to search effectively and assisting with their research activities.

The survey of government librarians identified similarities in the style and types of personalised services offered, with consistent emphasis on working in partnership and adding value, but variations in their specific remits and the methods of marketing, resourcing and measurement used, although there was also significant unanimity on lessons learned around clarifying user requirements, managing staff workloads and selective service targeting. The field research echoed the literature survey in confirming librarians' roles in both training end-users as searchers and acting as expert searchers contributing substantially to research, especially to support evidencebased practice. It also reinforced published messages on the importance of nurturing customer relationships, understanding the business and delivering quick, flexible responses. Most respondents recognised the importance of performance indicators, but like the rest of the profession were still trying to find definitive measures.

The study identified specific, interdependent issues for the DfES Library relating to the remit, marketing, resourcing and measurement of the proposed service, which can be seen as inherent tensions and management 
challenges of the model. In particular, it raised questions about the extent to which a Business Librarian would undertake substantive research work and include an 'account management' or ongoing liaison role: there are precedents in other government libraries and specialist information services, but this type of work might be difficult to resource through the flexible library-wide staffing arrangement envisaged. It also drew attention to the dilemma facing librarians who want to position themselves strategically, but must take care not to over-promote their services and create expectations they cannot meet.

The following recommendations to the DfES Library emerged from the study:

1. Define the service boundaries - identify relationships and overlaps with other parts of the Corporate Services and Development Directorate; decide whether liaison contacts or 'account management' forms part of the role; clarify customer requirements in relation to specific engagements; and establish any limits to work undertaken (e.g. carrying out research).

2. Market the service strategically - build a strong brand to reclaim information territory; promote Information Needs Assessments to target groups; get involved in business and project planning; communicate the services offered and policy on charging; exploit Customer Relationship Management tools and techniques; and use established channels of communication (e.g. meetings and email).

3. Use staff resources effectively - work collaboratively with other areas of the Corporate Services and Development Directorate; maintain flexibility in staffing the service; and develop the competence and independence of end-users.

4. Develop strategic performance indicators - investigate measures used by others in the Corporate Services and Development Directorate; and consider the use of a Balanced Scorecard.

The study also identified issues related to this project which would benefit from further research:

- Training and development needs of staff offering personalised, value-added services - this was highlighted in the literature and could include investigation of skills used by consultants in the wider business environment.

- Performance measurement and metrics for the value added by personalised library services - this was revealed as a weakness and could include exploration of practical implementations of the balanced scorecard.

- Models of service delivery for user populations that are geographically dispersed - this was cited as a problem for implementation by two government librarians, but does not seem to have been discussed in the literature. 


\section{Personalised service? Changing the role of the government librarian}

\section{Acknowledgement}

The authors gratefully acknowledge the contribution of the government librarians and DfES staff who participated in this research. They are particularly indebted to Helen Challinor of the DfES Library for proposing the study and providing assistance throughout the project.

\section{References}

[1] Chartered Institute of Library and Information Professionals, Healthcare Executive Advisory Group, Future Proofing the Profession, (CILIP, London, 2004). Available at:

http://www.cilip.org.uk/professionalguidance/sectors/health (accessed 16 April 2006).

[2] G. St Clair, Staffing the special library, In: A. Scammell (ed.), Handbook of Information Management, $8^{\text {th }}$ ed, (Aslib-IMI, London, 2001), pp. 43-71.

[3] R. Wittwer, Special libraries - how to survive in the twenty-first century, The Electronic Library 19(4) (2001) 221-224.

[4] J. O'Connor, CDL conference 2004: challenge and change in government libraries, State Librarian (Spring) (2005) 27-30. Available at: http://www.nglis.org.uk/spring05.pdf (accessed 16 April 2006).

[5] P. Gershon, Releasing Resources to the Front Line: Independent Review of Public Sector Efficiency, (HMSO, Norwich, 2004). Available at: http://www.hmtreasury.gov.uk/media/B2C/11/efficiency_review 120704.pdf (accessed 16 April 2006).

[6] R. Gaston, The changing role of the subject librarian, with a particular focus on UK developments, examined through a review of the literature, The New Review of Academic Librarianship, 7 (2001) 19-37.

[7] C.S. Scherrer and S. Jacobson, New measures for new roles: defining and measuring the current practices of health sciences librarians, Journal of the Medical Library Association 90(2) (2002) 164-172.

[8] J. Konieczko and C. Powell, Information centers that innovate. Information Outlook 7(1) (2003) 18-19,2122,25-27.

[9] J. Marfleet, Implementing customer relationship management in JPMorgan: new roles for information professionals, Business Information Review 21(1) (2004) 111-116.

[10]T. Glynn and C. Wu, New roles and opportunities for academic library liaisons: a survey and recommendations, Reference Services Review 31(2) (2003) 122-128.

[11] S.J.E. Sargeant and J. Harrison, Clinical librarianship in the UK: temporary trend or permanent profession? Part I: the role of the clinical librarian. Health Information and Libraries Journal 21(3) (2004) 173-181. 
[12] K. Taylor, The Changing Role of the Government Librarian: a Move Towards a Personalised Model of Service Provision as Proposed by the Department for Education and Skills Library, (Unpublished Masters dissertation, Department of Information Studies, University of Sheffield, 2005). Available at: http://dagda.shef.ac.uk/dissertations/2004-05/External/Taylor_Katherine_MALib.pdf (accessed 16 April 2006).

[13] R. Heseltine, The challenge of learning in cyberspace, Library Association Record 97(8) (1995) 432-433.

[14]P. Curtis, Bangor librarians face Internet threat, The Guardian (16 February) (2005) Available at: http://education.guardian.co.uk/higher/careers/story/0,1415829,00.html (accessed 16 April 2006).

[15] S. Pinfield, The changing role of subject librarians in academic libraries, Journal of Librarianship and Information Science 33(1) (2001) 32-38.

[16]R. Biddiscombe, Learning support professionals: the changing role of subject specialists in UK academic libraries, Program 36(4) (2002) 228-235.

[17]D.G. Frank and E.A. Howell, Information consulting in academe, In: M.A. Drake (ed.), Encyclopedia of Library and Information Science, $2^{\text {nd }}$ ed, (Marcel Dekker, New York, 2003), pp. 1294-1299.

[18]E. Hyams, From academic librarians to strategy consultants, Library and Information Update 4(7-8) (2005) 28-30.

[19]D.G. Frank, G.K. Raschke, J. Wood and J.Z. Yang, Information consulting: the key to success in academic libraries, Journal of Academic Librarianship 27(2) (2001) 90-96.

[20] J. Donham and C.W. Green, Developing a culture of collaboration: librarian as consultant, Journal of Academic Librarianship 30(4) (2004) 314-321.

[21] J. Peacock, Teaching skills for teaching librarians: postcards from the edge of the educational paradigm, Australian Academic and Research Libraries 32(1) (2001) 26-42.

[22] S. Court, When is a librarian a teacher? Library Association Record 103(4) (2001) 234-235.

[23] O. Beavan and J. McHugh, An introduction to evidence-based health care and the opportunities it presents for information professionals: clinical evidence as an example, VINE 33(4) (2003) 179-183.

[24]C.A. Beverley, A. Booth and P.A. Bath, The role of the information specialist in the systematic review process: a health information case study, Health Information and Libraries Journal 20(2) (2003) 65-74.

[25]D. Wilson, H. Bateman and P. Bailey, Early experience of the contribution of an information specialist within a primary healthcare team, Journal of Librarianship and Information Science 36(3) (2004) 127-134.

[26]J. Harrison and S.J.E. Sargeant, Clinical librarianship in the UK: temporary trend or permanent profession? Part II: present challenges and future opportunities, Health Information and Libraries Journal 21(4) (2004) 220-226. 


\section{Personalised service? Changing the role of the government librarian}

[27]I. Fourie, Librarians and the claiming of new roles: how can we try to make a difference? Aslib Proceedings, 56(1) (2004) 62-74.

[28]J. Palmer, A healthy profession? Library and Information Update 3(12) (2004) 32-33.

[29] A. Fricker, The NHS gets to grip with workforce development, Library and Information Update 3(12) (2004) 29-31.

[30]C.L. Shamel, Building a brand: got librarian? Searcher 10(7) (2002) 60-71.

[31]D. Barreau, The new information professional: Goldspiel Grant recipient compares vision to practise. Information Outlook 8(4) (2004) 31-32,34-35.

[32]F. Ryan, Surviving and thriving in a harsh world, Library and Information Update 4(5) (2005) 26-29.

[33]L. Brick, Non-use of business libraries and information services: a study of the library and information managers' perception, experience and reaction to non-use, Aslib Proceedings 51(6) (1999) 195-205.

[34] M. Cumming and L. Cuthbertson, Wired in Whitehall: a survey of Internet and intranet use in government, Aslib Proceedings 53(1) (2001) 32-38.

[35]P. Levay, Surviving and thriving: the fifth Police Librarians' Conference, State Librarian (Winter/Spring) (2003) 27-33. Available at: http://www.nglis.org.uk/winter-spring2002-2003.pdf (accessed 16 April 2006).

[36] J. Miller, Government libraries should be an educational experience, State Librarian (Winter/Spring) (2003) 23-26. Available at: http://www.nglis.org.uk/winter-spring2002-2003.pdf (accessed 16 April 2006).

[37] M. Cumming, A vision of the future, State Librarian (Autumn) (2004) 10-17. Available at: http://www.nglis.org.uk/autumn04.pdf (accessed 16 April 2006).

[38] S. Thornton and C. McCracken, Knowledge agents in Dstl, Managing Information 10(2) (2003) 32-34.

[39]R. Jones, Measuring the benefits of knowledge management at the Financial Services Authority: a case study, Journal of Information Science 29(6) (2003) 475-488.

[40]C. Gray, How knowledge became yellow, State Librarian (Autumn) (2004) 44-50. Available at: http://www.nglis.org.uk/autumn04.pdf (accessed 16 April 2006).

[41]D. Haynes, M. Field and L. Rees-Jones, Successful KM, Library and Information Update 1(8) (2002) 50-52.

[42] J. Parry, G. Harrison and C. Jacques, Sharing information across government, State Librarian (Autumn) (2004) 30-42. Available at: http://www.nglis.org.uk/autumn04.pdf (accessed 16 April 2006).

[43]F. Bell, Marketing the information service, In: A. Scammell (ed.), Handbook of Information Management, $8^{\text {th }}$ ed., (Aslib-IMI, London, 2001), pp. 353-368.

[44] A. Soules, The principles of marketing and relationship management, Portal: Libraries and the Academy 1(3) (2001) 339-350. 
[45] A. Brewerton, Inspired! Award-winning library marketing, New Library World 104(1190/1191) (2003) 267277.

[46]L.X. Besant and D. Sharp, Upsize this! Libraries need relationship marketing, Information Outlook 4(3) (2000) 17-22.

[47]E.E. de Saez, Marketing Concepts for Libraries and Information Services, 2nd ed., (Facet, London, 2002).

[48]I. Owens, Marketing in library and information services: a selected review of related literature, Acquisitions Librarian 28 (2002) 5-31.

[49]R. Singh, Developing relationship marketing with customers: a Scandinavian perspective, Library Management 24(1/2) (2003) 34-43.

[50] J. Finney, Brand values at the BL, Library and Information Update 2(2) (2003) 54-55.

[51]B. Dempsey, Target your brand, Library Journal 129(13) (2004) 32-35.

[52]L. Claggett, Identify your brand before you market, Information Outlook 6(11) (2002) 12-14,16.

[53]C.A. Olson, What's in it for them? Communicating the value of information services, Information Outlook 6(11) (2002) 18-23.

[54] J. Strand, Strike up the brand: how to market your value to the rest of the world, Information Outlook 8(5) (2004) 11-15.

[55]J. Matthews, Determining and communicating the value of the special library: valuing the balanced library scorecard, Information Outlook 7(3) (2003) 27-31.

[56]S. Parker and M. Crawford, Performance measurement and metrics, In: A. Scammell (ed.), Handbook of Information Management, $8^{\text {th }}$ ed., (Aslib-IMI, London, 2001), pp. 353-368.

[57]R. Poll, Performance, process and costs: managing service quality with the balanced scorecard. Library Trends 49(4) (2001) 709-717.

[58]C. Penzhorn and H. Pienaar, Using the balanced scorecard to facilitate strategic management at an academic information service. Libri 50(3) (2000) 202-209.

[59] J. Self, From values to metrics: implementation of the balanced scorecard at a university library. Performance Measurement and Metrics 4(2) (2003) 57-63.

[60]G. Cribb and C. Hogan, Balanced scorecard: linking strategic planning to measurement and communication. IATUL Proceedings (New Series) 13 (2003) Available at: http://iatul.org.conference/proceedings/vol13/papers/CRIBB_fulltext.pdf (accessed 16 April 2006).

[61]J. Krarup, Balanced scorecard at the Royal Library, Copenhagen. LIBER Quarterly 14(1) (2004) 37-57. 


\section{Personalised service? Changing the role of the government librarian}

[62]T. Aguado, Using the Balanced Scorecard in a Health Library: a Case Study (2005). Available at: http://www.gardinerlibrary.com/Default.aspx?id=112 (accessed 16 April 2005).

[63] A. Strauss and J. Corbin, Basics of Qualitative Research: Techniques and Procedures for Developing Grounded Theory, $2^{\text {nd }}$ ed. (Sage, Thousand Oaks, 1998) 